\title{
INVESTIGATION OF THE ROLE OF TEACHERS' FEATURES IN DETERMINING THE STUDENT COURSE SUCCESS
}

\author{
Davut HOTAMAN ${ }^{1}$
}

${ }^{1}$ Doç. Dr., Yıldız Teknik Üniversitesi, davut@yildiz.edu.tr, ORCID: 0000-0002-8715-2650

Hotaman, Davud. "Investigation of the role of teachers' features in determining the student course success". ulakbilge, 45 (2020 Şubat): s. 145-157. doi: 10.7816/ulakbilge-08-45-03

\begin{abstract}
If we define education as a "deliberate culturing" process, then it is clear that all educational activities need to be planned. Planning in education is pre-designing and organizing which of the educational activities to choose in order to achieve specific educational goals, why and how to make them available to students, what auxiliary and complementary resources and tools to use, and how to evaluate the achieved results. Teachers, who are the implementers of these programs, are one of the main inputs of the education system, as they closely monitor the output or product of the planned and scheduled educational application. In order to reach the most accurate and detailed evaluations about the quality of the outputs, teachers must examine the product from all aspects and collect data with the most accurate assessment tools for evaluation. The purpose of this study is to determine the extent to which teachers monitor and evaluate the observable in-class and out-of-class behaviors of students in the process of determining students' course success. In this respect, since the research is descriptive, singular scanning was used as a method. The research was carried out on volunteer class and branch teachers working in primary, secondary and high schools. This research is important in terms of emphasizing the need to consider the observation based in-and-out-of-class behaviors of the students in determining their course success. According to the results obtained, it was determined that while evaluating their students, teachers' levels of considering the students' observable in-and-out-of-class performance variables differed significantly according to the teachers' gender, field/branch, seniority and level/type of school in which they were assigned.
\end{abstract}

Keywords: Education, course success, assessment, evaluation 


\section{Introduction}

Communities invest in education in order to enrich their life processes, utilize their resources effectively, compete with other societies and guarantee their future. Education is an indispensable requirement for the individual's social cohesion and development and is one of the most important variables in preparing the individual and society for the future. In this sense, education can also be seen as a "deliberate culturing process". When the definitions related to education in the literature are examined, it is seen that the common points of these definitions are "realizing the targeted behavior changes targeted by the society through planned activities" (Bilen, 2012; Demirel, 2019; Görgen, 2014; Morrison at al, 2004 ; Ornstein \& Hunkins, 2009; Variş, 1996). Among these definitions, Ertürk's definition of education is accepted the most. Ertürk (1984, p.12) defines education as "the process of intentional and desired behavior change in the individual's behavior through his own experiences". This is a commonly used definition that includes formal education. The education process in every country is open to individuals in need of education. Training is a planned and deliberate process and is expected to be carried out according to the plans made. However, there is no guarantee that all planned educational activities will always yield expected results. Therefore, there is a need for continuous control of whether the plans are delivering the expected results. Failure of planned activities to achieve its goal means a waste of money, labor, energy, and thus, time.

Education is a series of planned activities. Therefore, all of the educational activities are carried out within a program, and plans designed for this purpose are called educational programs. An educational program consists of objectives, content, educational situations (learning experiences) and assessment (Bilen, 2012; Demirel, 2019; Görgen, 2014; Ornstein \&Hunkins, 2009). In education programs, first of all, the properties that are decided to be acquired by the student, namely the goal-achievements, are determined. These goal-achievements are desired characteristics that are approved by the society, decided to be brought to the individual and can be achieved through education (Bilen, 2012; Demirel, 2019; Ertürk, 1984; Görgen, 2014; Ornstein \& Hunkins, 2009; Variș, 1996). The second element of the education programs includes the characteristics that the target-achievements indicate, the third element is the educational status (learning experiences) and the fourth and the last element is the eval uation. Evaluation, which is the last element of the education programs, is the stage of checking whether or not the target achievements determined to be given to the students at the beginning of the process are translated into student behavior. No matter how effectively the training process is planned, it is required to determine whether the expectations are met by looking at the outputs at the end of the process (Baykul, 2000; Baykul, 2010; Baykul ve Turgut, 2015; Ertürk, 1984; Kan, 2015; Linn \& Miller, 2005; Ornstein \&Hunkins, 2009 ).

In order to be able to evaluate the education process, it is necessary to perform assessment procedures first. Assessment is done in order to determine to what extent an object or individual has a certain quality or feature (Kan, 2015, p.2). To this end, assessment tools that will determine whether the behaviors that are decided to be given to the student and desired to be given through education, are organized and applied to the students in the process and at the end of the process. That is to say that the behavioral changes acquired in the process are determined and then, expressed with numbers and symbols. Assessment and evaluation processes are the only way to shed light on making positive or negative decisions about planning, implementation and therefore the appropriateness of their output. In this sense, evaluation is an indispensable part of the education and training process (Başol, 2013, p.3; Kan, 2015; Popham, 2002; Turgut \& Baykul, 2010, p.69;). The variables that are tried to be observed or assessed in education are generally psychological variables like success, talent, interest, responsibility, motivation, perception, etc. The physical qualities of many of these variables are unknown and therefore their physical dimensions cannot be defined (Kan, 2015, p.2). Various assessment methods and techniques are used to assess and define these variables. The teacher should analyze the situations that are indicators of learning products that cannot be directly observed and follow these indicators. Effective monitoring of this process is very important in terms of teacher competencies (Gronlund, 2002).

The purpose of the evaluation is to objectively determine the degree of success of the application in a certain process (Bursalıoğlu, 1987). A judgment is made based on the data obtained in this process (Turgut \& Baykul, 2010). If a judgment will be made about the student's academic success, evaluating the student's every behavior of academic origin will increase the reliability and validity of the judiciary. For this purpose, it is emphasized that the observable in-school and out-of-school academic performance indicators accentuated in this research can be used for a valid and reliable judgment in determining student's course success. Therefore, by evaluating the students 
while taking into account their course grades, which are the markers of their academic achievement, and their observable performances both in and out of the class during the process, will contribute to the creation of more accurate judgments about the student (Başol, 2013). Assessment and evaluation processes in educational systems are important not only in terms of determining the academic success of the student, but also in revealing whether the required qualified manpower is reached (Stiggins, 1999). In addition, another aim of assessment is to improve and support student learning. A sensitive, accurate, appropriate, supportive assessment and evaluation is an indispensable part of all learning processes (Başol, 2013; Burke, 1994; Kaptan, 1999; Stronge, Tucker and Hindman, 2004; Tan, 2006; Vural, 2004).

\section{The Aim and Importance of the Study}

The purpose of this study is to determine the extent to which teachers working in public schools take into account observable variables based on classroom and out-of-class performance in determining students' course success. When deciding about students' course success, considering all kinds of student data will increase the validity and reliability of the assessment. This research is important in the sense that it emphasizes not only in-class and endterm classical or complementary assessment processes, but also the fact that student behaviors that require performance in and out of class should be taken into consideration.

\section{Problem:}

To what extent do teachers consider observable classroom and out-of-class performance variables when determining students' course success?

Sub Problems:

Do the observable classroom and out-of-class performance indicators that are taken into account in determining the academic success of the student differ according to the gender of the teachers?

Do the observable classroom and out-of-class performance indicators considered in determining the academic success of the student differ according to the branch of teachers?

Do the observable classroom and out-of-class performance indicators considered in determining the academic success of the student differ according to the seniority of the teachers?

Do the observable classroom and out-of-class performance indicators that are taken into account in determining the academic success of the student differ according to the level of the school where the teachers work?

\section{Method}

In this study one of the survey methods, "single screening" is used; moreover, this research is descriptive because it determines which and to what extent direct observation based variables have been used by the teachers working in the Ministry of National Education in order to consider the students' course success. Screening models provide a quantitative or numerical description of trends, attitudes or views across the population through studies on a sample selected from a population (Creswell, 2017; Karasar, 2005). In screening studies, information is collected from a wide audience using answer options determined by the researcher (Fraenkel \& Wallen, 2006). This method is used in researches trying to describe and explain what events, objects, assets, institutions, groups and various fields are (Kaptan, 1998), and the aims in these models are usually expressed in question sentences (Büyüköztürk, 2016). Single screening, which is one of the screening models, is known as the research model for determining the occurrence of variables individually or in quantity (Yin, 2003). In this type of model, the variables of the event, substance, individual or subject of interest are described (introduced) separately (Kıncal, 2010; Yıldırım \& Şimşek, 2011). In addition to instantaneous case determinations, temporal developments and changes can also be determined with single screening models (Karasar, 2005).

\section{Population and Sample}

The population of this research consists of teachers working in primary, secondary and high schools in Güngören district of Istanbul. The sampling of this research was 203 classroom teachers working in primary schools, 139 teachers working in secondary schools and 204 branch teacher working in high schools who were determined by the "simple random sampling" method and agreed to cooperate for research. 
Table 1. Demographic Features of the Sample

\begin{tabular}{|c|c|c|c|c|c|}
\hline Variables & & $\mathrm{f}$ & $\%$ & $\mathrm{f}$ & $\%$ (Total) \\
\hline \multirow[t]{2}{*}{ Sex } & Female & 336 & 61,5 & & \\
\hline & Male & 210 & 38,5 & 546 & 100.0 \\
\hline \multirow[t]{2}{*}{ Field/Branch } & Classroom Teacher & 196 & 35,9 & & \\
\hline & Branch Teacher & 350 & 64,1 & 546 & 100.0 \\
\hline \multirow[t]{6}{*}{ Seniority } & (1) 0-5 Year & 95 & 17,4 & & \\
\hline & (2) 6-9 Year & 116 & 21,2 & & \\
\hline & (3) 6-9 Year & 82 & 15,0 & 546 & 100.0 \\
\hline & (4) 6-9 Year & 77 & 14,1 & & \\
\hline & (5) 6-9 Year & 100 & 18,3 & & \\
\hline & (6) 6-9 Year & 76 & 13,9 & & \\
\hline \multirow[t]{3}{*}{ School Type } & (1) Primary School & 203 & 37,2 & & \\
\hline & (2) Secondary School & 139 & 25,5 & 546 & 100.0 \\
\hline & (3) High School & 204 & 37,4 & & \\
\hline
\end{tabular}

\section{Data Gathering Tool}

In this research, two-dimensional questionnaire developed by the researcher was used as a data collection tool. The first part of the questionnaire consists of four questions to collect demographic / personal data. These are gender, branch, seniority and school level in which they work. In its second dimension, there are fourteen (14) statements regarding the observable performance-based variables inside and outside the school that can be used to determine the student's course success. Each teacher gives a score of 5-1 to show how much they consider these propositions. These in-and-out-of-class performance based observable variables were gathered in a "pool" created with the opinions of fifty (50) cooperating teachers according to their branches, and two groups of similar and different variables were formed according to the branches of the teachers who suggested them. In this way, two observable classroom and out-of-class performance-based lists proposed by classroom teachers and branch teachers were created, and similarities and differences between the two lists were determined and turned into a single list. The level of compatibility between these two lists was determined to vary between 0.59 and 0.73 according to the formula of Cohens Kappa (1960). Kappa coefficient is the statistic that assesses the concordance between the two observers in the evaluation of categorical items (Cohen, 1960; Kılıç, 2015). Therefore, it can be said that the lower limit of the concordance level is in the "medium" range and the upper limit is in the "fairly good" range, so the result emerging according to the branches is at an acceptable "consistency" level. The content validity of the data collection tool is based on the "positive opinion" of the two field education experts. The frequency and percentage values of the categories obtained from each question are presented in a table. Some of the opinions of teacher candidates are also presented in the text.

\section{Gathering and Analyzing Data}

The data obtained from the data collection tool were analyzed by using descriptive analysis method. The descriptive analysis approach allows the data to be organized according to the themes posed by the research questions and to be presented by considering the questions or dimensions used in the interview (Yıldırım \& Şimşek, 2003). The data collected on teachers' levels of using observable, in and out of class performance-based variables in determining students' academic success was analyzed using SPSS 15.0 statistical analysis program. In the analysis of the data, the views of the teachers determined for each question were converted into percentage (\%) and frequency (f) tables, and chi-square was used for two variables to determine whether the observations between groups were distributed differently. Chi-Square is a good-fit (goodness of fit) test for single samples that test whether individuals or objects entering the levels of categorical variables show a significant difference (Büyüköztürk, 2007).

\section{Findings}

In this section, the findings related to the research problem are given respectively. Firstly, the data obtained from the sample group are presented as frequency and \%s according to demographic variables. 
Table 2. Frequency, \% distribution and Chi-Square Test Results of observable classroom performance indicators of students that teachers consider according to gender variable.

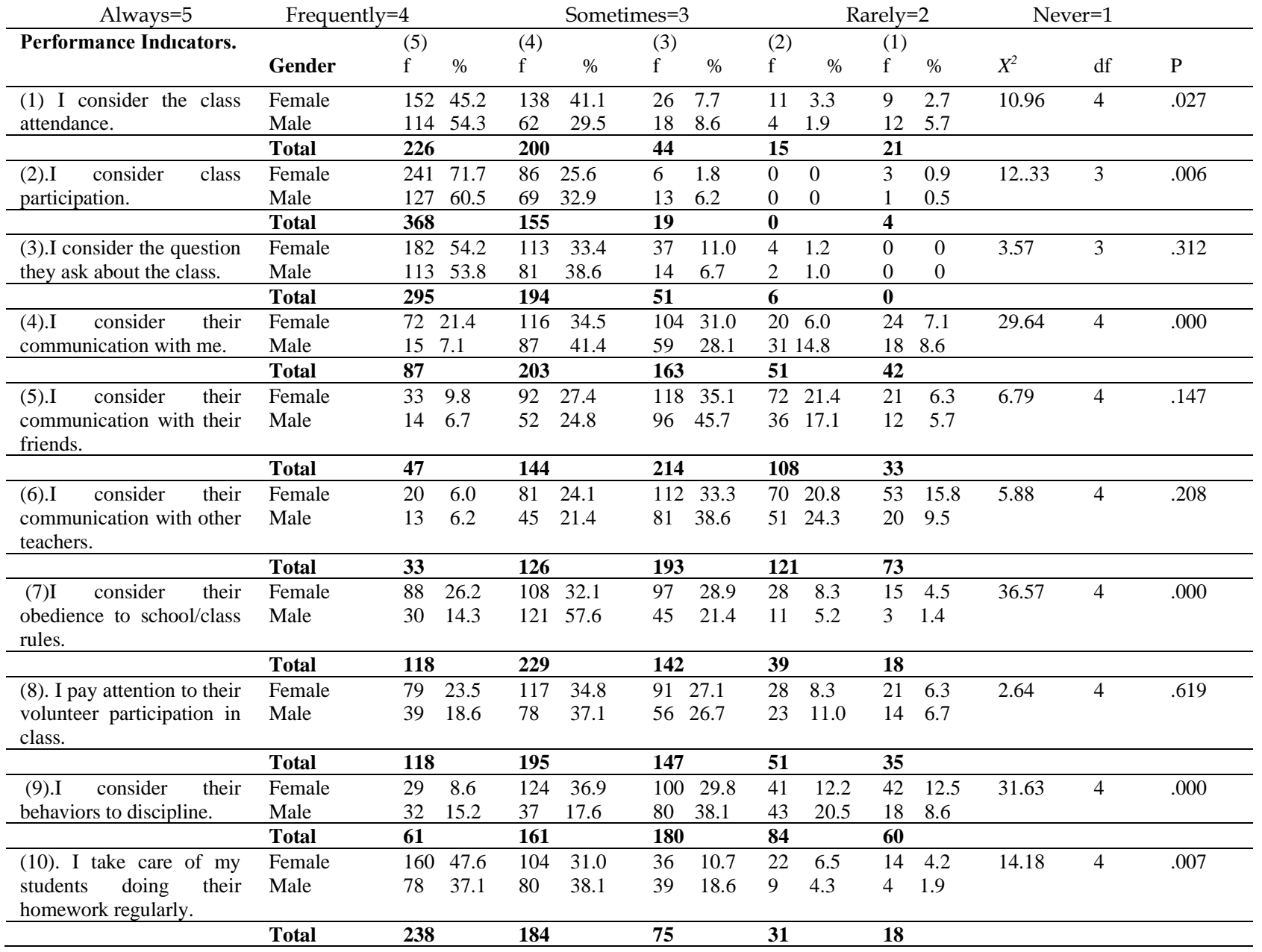

Table 2 gives the results of the variables according to the gender of the teachers which they take into consideration while determining the course success of the students based on observable student performance in the classroom. Considering the table and chi-square $\left(x^{2}\right)$ results applied to the data obtained with the data collection tool, it is seen that "female" and "male" teachers are involved in different practices regarding the variables expressed by questions 1, 2, 4, 7, 9 and 10. In other words, it was observed that while determining the academic success of the student, they differed in considering variables based on observable student performance.

Table 3 contains data on whether the observable classroom performance variables taken into account during the determination of the student's course success differ significantly according to the fields/branches of the teachers. When the related table is analyzed, it was seen that, apart from the 5th question, in the other 9 questions, classroom teachers and branch teachers differed in considering the variables based on observable student performance while determining the academic success of the student. 
Table 3. Frequency, \% distribution and Chi-Square Test Results of observable classroom performance indicators of students that teachers consider according to their field/branch variable

\begin{tabular}{|c|c|c|c|c|c|c|c|c|c|c|c|c|c|}
\hline \multirow{3}{*}{$\begin{array}{c}\text { Always }=5 \\
\text { Performance Indicators. }\end{array}$} & \multicolumn{3}{|c|}{ Frequently=4 } & \multicolumn{4}{|c|}{ Sometimes $=3$} & \multicolumn{3}{|c|}{ Rarely $=2$} & \multicolumn{2}{|c|}{ Never $=1$} & \multirow[b]{3}{*}{$\mathrm{p}$} \\
\hline & \multirow{2}{*}{ Field/Branch } & \multicolumn{2}{|l|}{ (5) } & \multicolumn{2}{|l|}{ (4) } & \multicolumn{2}{|l|}{ (3) } & (2) & \multicolumn{2}{|c|}{ (1) } & \multirow[b]{2}{*}{$X^{2}$} & \multirow[b]{2}{*}{ df } & \\
\hline & & f & $\%$ & $\mathrm{f}$ & $\%$ & f & $\%$ & $\%$ & f & $\%$ & & & \\
\hline (1) I consider the class & Clss. Tchr. & 133 & 67.9 & 28 & 14.3 & 19 & 9.7 & 1.5 & 13 & 6.6 & 73.500 & 4 & .000 \\
\hline & Total & 266 & & 200 & & 44 & & 15 & 21 & & & & \\
\hline (2).I consider & Clss. Tchr. & 144 & 73.5 & 46 & 23.5 & 2 & 1.0 & 0 & 4 & 2.0 & 16.735 & 3 & .001 \\
\hline \multirow[t]{2}{*}{ participation. } & Brch. Tchr & 224 & 64.0 & 109 & 31.1 & 17 & 4.9 & 0.0 & 0 & 0.0 & & & \\
\hline & Total & 368 & & 155 & & 19 & & $\mathbf{0}$ & 4 & & & & \\
\hline \multirow{3}{*}{ they ask about the class. } & Clss. Tchr. & 120 & 61.2 & 61 & 31.1 & 10 & 5.1 & 2.6 & 0 & 0.0 & 16.351 & 3 & .001 \\
\hline & Brch. Tchr & 175 & 50.0 & 133 & 38.0 & 41 & 11.7 & 03 & 0 & 0.0 & & & \\
\hline & Total & 295 & & 194 & & 51 & & 6 & $\mathbf{0}$ & & & & \\
\hline (4).I consider their & Clss. Tchr. & 35 & 17.9 & 72 & 36.7 & 46 & 23.5 & 168.2 & 27 & 13.8 & 23.063 & 4 & .000 \\
\hline \multirow[t]{2}{*}{ communication with me. } & Brch. Tchr & 52 & 14.9 & 131 & 37.4 & 117 & 33.4 & 3510.0 & 15 & 4.3 & & & \\
\hline & Total & 87 & & 203 & & 163 & & 51 & 42 & & & & \\
\hline \multirow{3}{*}{$\begin{array}{l}\text { (5).I consider their } \\
\text { communication with their } \\
\text { friends. }\end{array}$} & Clss. Tchr. & 21 & 10.7 & 46 & 23.5 & 79 & 40.3 & 3618.4 & 14 & 7.1 & 3.570 & 4 & .467 \\
\hline & Brch. Tchr & 26 & 7.4 & 98 & 28.0 & 135 & 38.6 & 7220.6 & 19 & 5.4 & & & \\
\hline & Total & 47 & & 144 & & 214 & & 109 & 33 & & & & \\
\hline \multirow{3}{*}{$\begin{array}{l}\text { (6).I consider their } \\
\text { communication with other } \\
\text { teachers. }\end{array}$} & Clss. Tchr. & 11 & 5.6 & 46 & 23.5 & 51 & 26.0 & 5327.0 & 35 & 17.9 & 15.530 & 4 & .004 \\
\hline & Brch. Tchr & 22 & 6.3 & 80 & 22.9 & 142 & 40.6 & 6819.4 & 38 & 10.9 & & & \\
\hline & Total & 33 & & 126 & & 193 & & 121 & 73 & & & & \\
\hline \multirow{3}{*}{$\begin{array}{l}(7) \mathrm{I} \text { consider their } \\
\text { obedience to school/class } \\
\text { rules. }\end{array}$} & Clss. Tchr. & & 25.5 & 78 & 39.8 & 38 & 19.4 & 2110.7 & 9 & 4.6 & 14.653 & 4 & .005 \\
\hline & Brch. Tchr & 68 & 19.4 & 151 & 43.1 & 104 & 29.7 & 185.1 & 9 & 2.6 & & & \\
\hline & Total & 118 & & 229 & & 142 & & 39 & 18 & & & & \\
\hline \multirow{3}{*}{$\begin{array}{l}\text { ( } 8) \text {. I pay attention to their } \\
\text { volunteer participation in } \\
\text { class. }\end{array}$} & Clss. Tchr. & 35 & 17.9 & 69 & 35.2 & & 23.5 & 3618.4 & 10 & 5.1 & 30.860 & 4 & .000 \\
\hline & Brch. Tchr & 832 & 23.7 & 126 & 36.0 & 101 & 28.9 & 154.3 & 25 & 7.1 & & & \\
\hline & Total & 118 & & 195 & & 147 & & 51 & 35 & & & & \\
\hline \multirow{3}{*}{$\begin{array}{l}\text { (9).I consider their } \\
\text { behaviors to discipline. }\end{array}$} & Clss. Tchr. & 26 & 13.3 & 42 & 21.4 & 66 & 33.7 & 3015.3 & 32 & 16.3 & 15.907 & 4 & .003 \\
\hline & Brch. Tchr & 35 & 10.0 & 119 & 34.0 & 114 & 32.6 & 5415.4 & 28 & 8.0 & & & \\
\hline & Total & 61 & & 161 & & 180 & & 84 & 60 & & & & \\
\hline $\begin{array}{l}\text { (10). I take care of my } \\
\text { students doing their } \\
\text { homework regularly. }\end{array}$ & Total & 238 & & 184 & & 75 & & 31 & 118 & & & & \\
\hline
\end{tabular}

Table 4 contains data on whether the observable classroom performance variables taken into account during the determination of the student's course success differ significantly according to the seniority of the teachers. When the related table was analyzed, it was seen that, apart from the 6th and 7th questions, the 8 different questions differed in considering the variables based on observable student performance while determining the academic success of the student according to the teachers' seniority status. 
Table 4. Frequency, \% distribution and Chi-Square Test Results of observable classroom performance indicators of students that teachers consider according to their seniority variable.

\begin{tabular}{|c|c|c|c|c|c|c|c|c|c|c|c|c|c|c|}
\hline \multirow{3}{*}{$\frac{\text { Always }=5 \quad \text { Freque }}{\text { Performance Indicators }}$} & \multirow{3}{*}{$\begin{array}{l}\text { atly=4 } \\
\text { Seniority } \\
\text { Status }\end{array}$} & \multicolumn{4}{|c|}{ Sometimes $=3$} & \multicolumn{4}{|c|}{ Rarely $=2$} & \multicolumn{3}{|c|}{ Never $=1$} & \multirow[b]{3}{*}{ df } & \multirow[b]{3}{*}{$\mathrm{p}$} \\
\hline & & (5) & & (4) & & (3) & & $(2)$ & & (1) & & & & \\
\hline & & $\mathrm{f}$ & $\%$ & f & $\%$ & $\mathrm{f}$ & $\%$ & $\mathrm{f}$ & $\%$ & f & $\%$ & $X^{2}$ & & \\
\hline (1) I consider the class & $(1) .0-5$ & 42 & 44.2 & 46 & 48.4 & 3 & 3.2 & 3 & 3.2 & 1 & 1.1 & & & \\
\hline attendance. & (2).6-9 & 56 & 48.3 & 47 & 40.5 & 7 & 6.0 & 2 & 1.7 & 4 & 3.4 & 37.786 & 20 & .009 \\
\hline & (3). $10-15$ & 42 & 51.2 & 24 & 29.3 & 12 & 14.6 & 1 & 1.2 & 3 & 3.7 & & & \\
\hline & (4). $16-20$ & 34 & 44.2 & 27 & 35.1 & 9 & 11.7 & 5 & 6.5 & 2 & 2.6 & & & \\
\hline & (5).21-26 & 46 & 46.0 & 38 & 38.0 & 10 & 10.0 & 0 & 0.0 & 6 & 6.0 & & & \\
\hline & (6).27-High & 46 & 60.5 & 18 & 23.7 & 3 & 3.9 & 45 & 5.3 & 5 & 6.6 & & & \\
\hline & Total & 266 & 48.7 & 200 & 36.6 & 44 & 8.1 & 15 & 2.7 & & 3.8 & & & \\
\hline (2).I $\quad$ consider & (1).0-5 & 60 & 63.2 & 30 & 31.6 & 5 & 5.3 & 0 & 0.0 & 0 & 0.0 & & & \\
\hline participation. & (2).6-9 & 73 & 62.9 & 40 & 34.5 & 3 & 2.6 & 0 & 0.0 & 0 & 0.0 & 29.134 & 15 & .015 \\
\hline & (3). $10-15$ & 61 & 74.4 & 16 & 19.5 & 5 & 6.1 & 0 & 0.0 & 0 & 0.0 & & & \\
\hline & (4). $16-20$ & 45 & 58.4 & 27 & 35.1 & 5 & 6.5 & 0 & 0.0 & 0 & 0.0 & & & \\
\hline & (5).21-26 & 72 & 72.0 & 25 & 25.0 & 0 & 0.0 & 0 & 0.0 & 3 & 3.0 & & & \\
\hline & (6).27-High & 57 & 75.0 & 17 & 22.4 & 1 & 1.3 & 0 & 0.0 & 1 & 1.3 & & & \\
\hline & Total & 368 & 67.4 & 155 & 28.4 & 19 & 3.5 & 0 & 00 & 4 & 0.7 & & & \\
\hline (3).I consider the question they & (1). $0-5$ & 46 & 48.4 & 42 & 43.2 & 7 & 7.4 & 1 & 1.1 & 0 & 0.0 & & & \\
\hline ask about the class. & (2).6-9 & 60 & 51.7 & 42 & 36.2 & 14 & 12.1 & 0 & 0.0 & 0 & 0.0 & 26.843 & 15 & .030 \\
\hline & (5).21-26 & 53 & 53.0 & 34 & 34.0 & 8 & 8.0 & 5 & 5.0 & 0 & 0.0 & & & \\
\hline & (6).27-High & 50 & 65.8 & 19 & 25.0 & 7 & 9.2 & 0 & 0.0 & 0 & 0.0 & & & \\
\hline & Total & 295 & 54.0 & 194 & 35.5 & 51 & 9.3 & 6 & 1.1 & 0 & 0.0 & & & \\
\hline $\begin{array}{lll}\text { (4).I } & \text { consider } & \text { their }\end{array}$ & (1).0-5 & 21 & 22.1 & 32 & 33.7 & 26 & 27.4 & 13 & 13.7 & 3 & 3.2 & & & \\
\hline communication with me. & (2).6-9 & 33 & 28.4 & 40 & 34.5 & 34 & 29.3 & 7 & 6.0 & 2 & 1.7 & 63.058 & 20 & .000 \\
\hline & (3). $10-15$ & 11 & 13.4 & 41 & 50.0 & 18 & 22.0 & 4 & 4.9 & 8 & 9.8 & & & \\
\hline & (4). $16-20$ & 8 & 10.4 & 33 & 42.9 & 24 & 31.2 & 8 & 10.4 & 4 & 5.2 & & & \\
\hline & (5).21-26 & 3 & 3.0 & 35 & 35.0 & 37 & 37.0 & 13 & 13.0 & & 12.0 & & & \\
\hline & (6).27-High & 11 & 14.5 & 22 & 28.9 & 24 & 31.6 & 6 & 7.9 & & 17.1 & & & \\
\hline & Total & 87 & 15.9 & 203 & 37.2 & 163 & 29.9 & 51 & 9.3 & 42 & 7.7 & & & \\
\hline $\begin{array}{lll}\text { (5).I } & \text { consider } & \text { their }\end{array}$ & 1).0-5 & 5 & 5.3 & 23 & 24.2 & 47 & 49.5 & 15 & 15.8 & 5 & 5.3 & & & \\
\hline communication with their & (2).6-9 & 14 & 12.1 & 30 & 25.9 & 33 & 28.4 & 34 & 29.3 & 5 & 4.3 & 34.697 & 20 & .022 \\
\hline friends. & (3). $10-15$ & 10 & 12.2 & 23 & 28.0 & 29 & 35.4 & 15 & 18.3 & 5 & 6.1 & & & \\
\hline & (4). $16-20$ & 7 & 9.1 & 15 & 19.5 & 35 & 45.5 & 17 & 22.1 & 3 & 3.9 & & & \\
\hline & (5).21-26 & 3 & 3.0 & 33 & 33.0 & 45 & 45.0 & 10 & 10.0 & 9 & 9.0 & & & \\
\hline & (6).27-High & 8 & 10.5 & 20 & 26.3 & 25 & 32.9 & 17 & 22.4 & 6 & 7.9 & & & \\
\hline & Total & 47 & 8.6 & 144 & 26.4 & 214 & 39.2 & 108 & 19.8 & 33 & 6.0 & & & \\
\hline $\begin{array}{lll}\text { (6).I } & \text { consider } & \text { their }\end{array}$ & (1).0-5 & 6 & 6.3 & 22 & 23.2 & 41 & 43.2 & 19 & 20.0 & 7 & 7.4 & & & \\
\hline & (4). $16-20$ & 4 & 5.2 & 15 & 19.5 & 23 & 29.9 & 27 & 35.1 & & 10.4 & & & \\
\hline & (5). $21-26$ & 4 & 4.0 & 22 & 22.0 & 37 & 37.0 & 19 & 19.0 & & 18.0 & & & \\
\hline & (6).27-High & 4 & 5.3 & 21 & 27.6 & 25 & 32.9 & 13 & 17.1 & & 17.1 & & & \\
\hline & Total & 33 & 6.0 & 126 & 23.1 & 193 & 35.3 & 121 & 22.2 & & 13.4 & & & \\
\hline (7)I consider their obedience & (1).0-5 & 24 & 25.3 & 33 & 34.7 & 28 & 29.5 & 7 & 7.4 & 3 & 3.2 & & & \\
\hline to school/class rules. & (2).6-9 & 20 & 17.2 & 52 & 44.8 & 35 & 30.2 & 8 & 6.9 & 1 & 0.9 & 25.662 & 20 & .177 \\
\hline & (3). $10-15$ & 20 & 24.4 & 35 & 42.7 & 21 & 25.6 & 5 & 6.1 & 1 & 1.2 & & & \\
\hline & (4). $16-20$ & 13 & 16.9 & 42 & 54.5 & 18 & 23.4 & 2 & 2.6 & 2 & 2.6 & & & \\
\hline & (5). $21-26$ & 23 & 23.0 & 40 & 40.0 & 20 & 20.0 & 12 & 12.0 & 5 & 5.0 & & & \\
\hline & (6).27-High & 18 & 23.7 & 27 & 35.5 & 20 & 26.3 & 5 & 6.6 & 6 & 7.9 & & & \\
\hline & Total & 118 & 21.6 & 229 & 41.9 & 142 & 26.0 & 39 & 7.1 & 18 & 3.3 & & & \\
\hline (8). I pay attention to their & (1). $0-5$ & 17 & 17.9 & 29 & 30.5 & 33 & 34.7 & 6 & 6.3 & & 10.5 & & & \\
\hline volunteer participation in class. & (2).6-9 & 35 & 30.2 & 42 & 36.2 & 29 & 25.0 & 52 & 4.3 & 5 & 4.3 & 56.850 & 20 & .000 \\
\hline & (3). $10-15$ & 17 & 20.7 & 41 & 50.0 & 17 & 20.7 & 56 & 6.1 & 2 & 2.4 & & & \\
\hline & (4). $16-20$ & 10 & 13.0 & 25 & 32.5 & 29 & 37.7 & 45 & 5.2 & 9 & 11.7 & & & \\
\hline & (5). $21-26$ & 20 & 20.0 & 33 & 33.0 & 22 & 22.0 & 22 & 22.0 & 3 & 3.0 & & & \\
\hline & (6).27-High & 19 & 25.0 & 25 & 32.9 & 17 & 22.4 & $9 \quad 1$ & 11.8 & 6 & 7.9 & & & \\
\hline & Total & 118 & 21.6 & 195 & 35.7 & 147 & 26.9 & 51 & 9.3 & 35 & 6.4 & & & \\
\hline (9).I consider their behaviors & (1).0-5 & 10 & 10.5 & 29 & 30.5 & 33 & 34.7 & 11 & 11.6 & & 12.6 & & & \\
\hline to discipline. & (2).6-9 & 13 & 11.2 & 35 & 30.2 & 35 & 30.2 & 22 & 19.0 & & 9.5 & 43.552 & 20 & .002 \\
\hline & (3). $10-15$ & 10 & 12.2 & 18 & 22.0 & 35 & 42.7 & 16 & 19.5 & 3 & 3.7 & & & \\
\hline & (4). $16-20$ & 3 & 3.9 & 29 & 37.7 & 31 & 40.3 & 11 & 14.3 & 3 & 3.9 & & & \\
\hline & (5).21-26 & 18 & 18.0 & 31 & 31.0 & 19 & 19.0 & 17 & 17.0 & 15 & 15.0 & & & \\
\hline & (6).27-High & 7 & 9.2 & 19 & 25.0 & 27 & 35.5 & 7 & 9.2 & 16 & 21.1 & & & \\
\hline & Total & 61 & 11.2 & 161 & 29.5 & 180 & 33.0 & 84 & 15.4 & 60 & 11.0 & & & \\
\hline (10). I take care of my students & (1).0-5 & 50 & 52.6 & 27 & 28.4 & 10 & 10.5 & 5 & 5.3 & 3 & 3.2 & & & \\
\hline doing their homework & (2).6-9 & 56 & 48.3 & 38 & 32.8 & 12 & 10.3 & 2 & 1.7 & 8 & 6.9 & 64.105 & 20 & .000 \\
\hline regularly. & (3). $10-15$ & 28 & 34.1 & 37 & 45.1 & 13 & 15.9 & 4 & 4.9 & 0 & 0.0 & & & \\
\hline
\end{tabular}




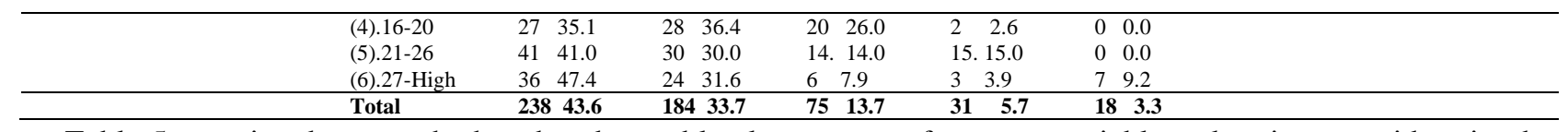

Table 5 contains data on whether the observable classroom performance variables taken into consideration by the teachers, in the process of determining the student's success differ significantly according to the schools they teach. When the related table was analyzed, it was seen that, apart from the 5 th question, in the other 9 questions, teachers differed in considering the variables based on observable student performance while determining the academic success of the student according to the variable of the level of school they work.

Table 5. Frequency, \% distribution and Chi-Square Test Results of observable classroom performance indicators of students that teachers consider according to their school type.

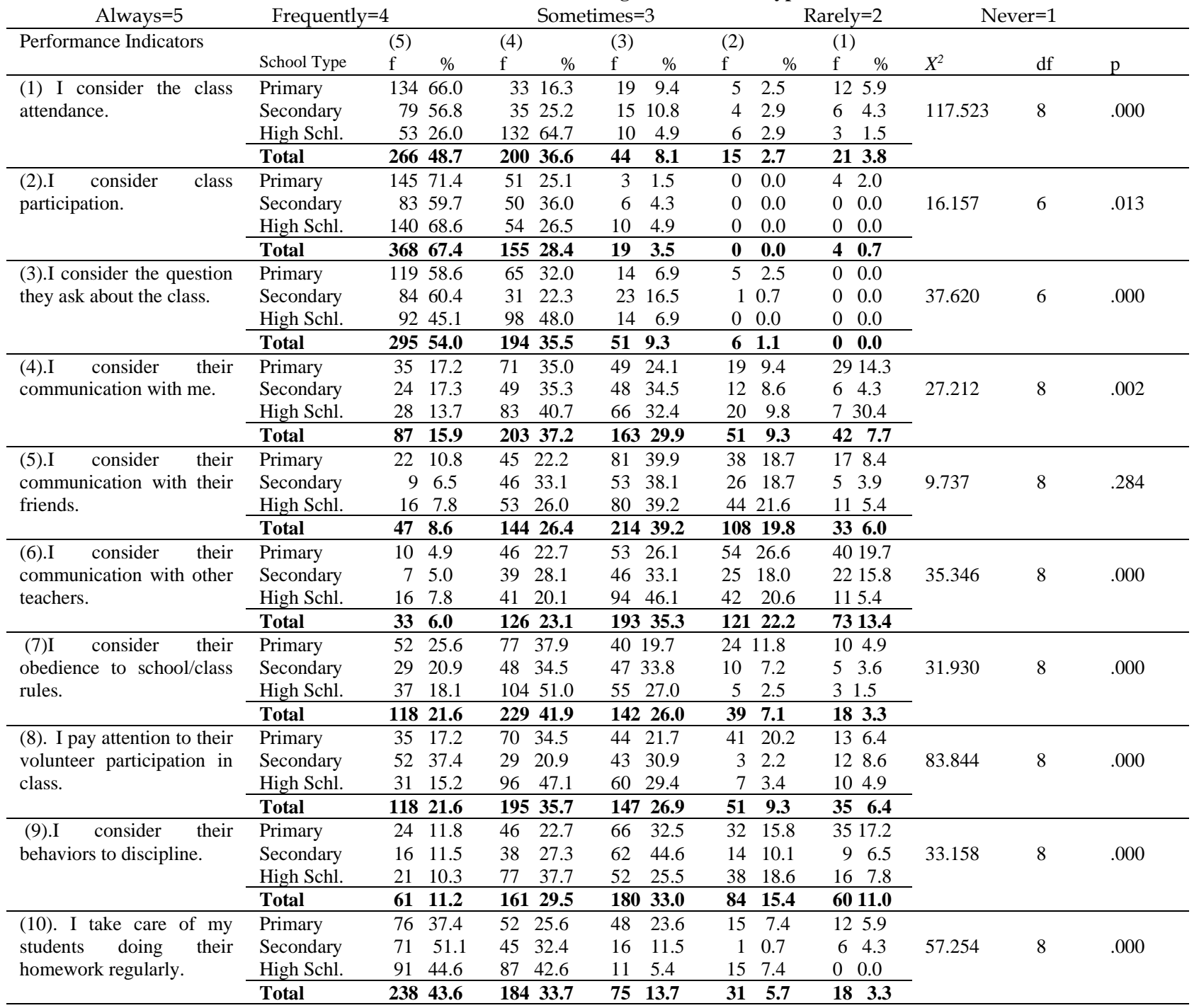

\section{Discussion and Conclusion}

Whether the education-training process has achieved the targeted change is determined by assessment and 
evaluation processes. Decision makers need assessment and evaluation results for ensuring the accuracy of their decisions, while practitioners need it to teach and students to learn. Therefore, assessment and evaluation processes are important for all education stakeholders. For healthy, correct, valid and reliable evaluations, the student's course success can be determined by taking into account all the correct scales and performance-based variables that are indicators of the academic success of the student. In terms of education, success is the student's achievement of the goals set in the curriculum. Accordingly, each school tries to create the best educational program that will help students achieve these goals. Planning the curriculum, choosing better equipment, directing teachers to specific in service studies, making use of the latest technological tools and spending money on education are among the activities aimed at increasing student success.

As of today, the tendency of determining one's academic success based on quantitative data is quite common which results in meeting with criticisms such as "the education system turns students into test machines". However, it is considered that the addition to quantitative data, adding qualitative data to the assessment process will mitigate this criticism as well as positively affect the determination of the student's true academic success. Moreover, for students, it is estimated that in determining students' course success, their teachers' knowledge of the observable variables based on performance, their level of attention would positively affect their self-control and participation in the class.

This research was carried out with the assumption that while determining the academic success of the student about the course, instead of going to a result only with the numerical data obtained with the classical assessment tools, considering the performance of the student with regard to the observable course will affect the decisions about the real success or failure of the student positively. Many studies show that teachers lack knowledge and practice in terms of assessment and evaluation (Birgin, 2006; Çakan, 2004; Erdal, 2007; Yapic1 ve Demirdelen 2007; Gözütok Akgün ve Karacaoğlu 2005; Özsevgeç, Çepni ve Demircioğlu, 2004; Yaşar, Gültekin, Türkkan, Yıldız ve Girmen, 2005; Yaşar et al, 2005). However, teachers need realistic feedback on what and how much they can teach. This feedback will also have a quality to guide the next lesson practices. Therefore, it is a professional responsibility and necessity that teachers determine what they teach or what the student learn in a healthy way.

The research findings show that while teachers determine the academic success of students regarding the course, they differ greatly according to gender, area/branch, seniority and the level of school in which they work. It is not deemed suitable for the teaching profession that people who became "teachers" through the same or similar education process, use different assessment and evaluation practices for such an important subject such as assessment and evaluation. It is considered that reaching an adequate level of knowledge and practice in the field will positively affect achieving objective and healthy results. Assessment and evaluation are an important part of every educational process and the basic element of the qualifications search in education. The main purpose of assessment and evaluation is to assess and improve the quality of education. Accordingly, repeatable and reliable evaluation methods should be used. The success of an education system parallels with the evaluation methods suitable to the philosophy of the system.

\section{Suggestions}

1. It is thought that it would be beneficial to include teachers in refresher trainings in parallel with the developments and research findings on "assessment and evaluation".

2. Ministry of Education's (MEB) identifying the problems faced by teachers in assessment and evaluation by would shed light on supportive practices.

3. It is estimated that all teachers would be able to contribute to the elimination of the problem by remembering that their profession is "a professional occupation", following the developments in assessment and evaluation, and transferring them to their students.

\section{Kaynaklar}

Anderson, L.W. (2008). Classroom assessment: Enhancing the quality of teacher decision

making. New Jersey: Lawrence Erlbaum Associates. 
Baykul, Y. Ve Turgut, F. (2015). Eğitimde ölme ve değerlendirme. Ankara: Pegem Akademi.

Baykul, Y. (1992). Eğitim sisteminde değerlendirme [Assessment in educational system].

Hacettepe Üniversitesi Eğitim Fakültesi Dergisi, 7, 85-94.

Baykul, Y. (2000). Eğitimde ve psikolojide ölçme: Klasik test teorisi ve uygulaması

[Measurement in education and psychology: Classical test theory and application]. Ankara: Öğrenci Seçme ve Yerleştirme Merkezi Yayınları.

Başol, G. (2013). Eğitimde ölçme ve değerlendirme (2. Baskı). Ankara: Pegem Akademi.

Baxer, J.A., \& Lederman, N.G., (1999). Assessment and measurement of pedagogical content

knowlege. In J. Gess-Newsome and N. G. Lederman (Eds.), Examining Pedagogical Content Knowledge: PCK and Science Education (pp. 147-161). Netherlands: Kluwer Academic Publisher.

Berberoğlu, G. (2006). Sinıf içi ölçme ve değerlendirme teknikleri. Ankara: Morpa Kültür Yayınları.

Bilen, M. (2012) Planlamadan Uygulamaya Öğretim, Anı Yayıncılık, ANKARA.

Bircan, H., Karagöz, Y. ve Kasapoğlu, Y. (2003), "Ki-Kare ve Kolmogorov Smirnov Uygunluk

Testlerinin Similasyon ile Elde Edilen Veriler Üzerinde Karşılaştırılması”, Cumhuriyet Üniversitesi İktisadi ve İdari Bilimler Dergisi, Cilt: 4, Sayı: 1, Sivas.

Büyüköztürk, Ş.(2016). Bilimsel araştırma yöntemleri.(22.bas.). Ankara: Pegem Akademi Yayıncılık. Ankara.

Çakan, M. (2004). Öğretmenlerin Ölçme-Değerlendirme Uygulamaları ve Yeterlik Düzeyleri: İlk ve Ortaöğretim. Ankara Üniversitesi Eğitim Fakültesi Dergisi, 37 (2), 99-114.

Cheng, M.H. (2006). Junior secondary science teachers' understanding and practice of alternative assessment in Hong Kong: Implications for teacher professional development. Canadian Journal of Science, Mathematics and Technology Education, 6(3), 227-243.

Cohen J. A (1960). A coefficient of agreement for nominal scales, Educational and Psychological Measurement. 1960; 20:37-46.

Cohen, L. \& Manion, L. (1998). Research methods in education. London:Routledge.

Creswell, J.W. (2009). Research design: Quantitative, qualitative, and mixed methods approaches. $3^{\text {rd }}$ ed. Thousand Oaks, CA: Sage.

Demirel, Ö. (2019). Eğitimde program geliştirme: Kuramdan Uygulamaya (26. Bask1). Ankara: PegemA Yayıncılık.

Erdal, H. (2007). 2005 İlköğretim Matematik Programı Ölçme Değerlendirme Kısmının İncelenmesi (Afyonkarahisar İli Örneği). Yayınlanmamış Yüksek Lisans Tezi, Afyon Kocatepe Üniversitesi, Sosyal Bilimler Enstitüsü.

Ertürk, S. (1984). Eğitimde program geliştirme (5. Bask1). Ankara: Meteksan.

Fraenkel, J. R. \& Wallen, N. E. (2006). How to design and evaluate research in education $\left(6^{\text {th }}\right.$ ed.). New York, NY: McGraw-Hill.

Görgen, İ. (2014). Program Geliştirmede Temel Kavramlar. Edit. Hasan Şeker, İçinde:

Eğitimde Program Geliştirme (3. Bask1). ss.1-18. Ankara: Anı yayıncılık.

Gözütok, D., Ö. E. Akgün ve C. Karacaoğlu (2005). İlköğretim programlarının öğretmen 
yeterlilikleri açısından değerlendirilmesi. Yeni İlköğretim programlarını değerlendirme sempozyumu, 14-16 Kasım 2005, Kayseri. 17-39

Gronlund, N.E. (2002). Assessment of student achievement (8th ed.). Needham Heights, MA: Pearson Allyn \& Bacon.

James, A.R., Griffin, L.L., \& France, T. (2005). Perceptions of assessment in elementary physical education: A case study. Physical Educator, 62(2), 85-95.

Kan, A. (2015). Ölçmenin Temel Kavramları, Edit.: Hakan Atılgan, İçinde, Eğitimde Ölçme ve Değerlendirme (8. Baskı). s.1-22. Ankara: Anı yayıncılık.

Kaptan, S. (1998). Bilimsel araştırma ve istatistik teknikleri (11.Bask1). Ankara: Tek Işı1k Web Ofset.

Karasar, N. (2005). Bilimsel araştırma yöntemi. Ankara: Nobel Yayın Dă̆ııım.

Kıncal, R. (2010). Bilimsel araştırma yöntemleri. Ankara: Nobel Yayın Dağıtım.(ISBN 978605-395-280-0)

Linn, R. L. \& Miller, D. M. (2005). Measurement and assessment in teaching (9th ed.). Saddle River, NJ: Prentice Hall.

Morrison, G. R., Ross, S. M. \& Kemp, J. E. (2004). Designing effective instruction. John Willey \& Sons Inc: USA.

Neuman, W.L. (2006). Social Research Methods: Qualitative and Quantitative Approaches. $6^{\text {th }}$ ed. Boston, MA: Pearson.

Ornstein, A. C. ve Hunkins, F. P. (2009). Curriculum; foundations, principles and lssues (Fifth Edition). Pearson Education, Inc.

Özsevgeç, T., Çepni, S., \& Demircioğlu, G. (2004). Fen Bilgisi Öğretmenlerin Ölçme-

Değerlendirme Okur-Yazarlık Düzeyleri. VI. Ulusal Fen Bilimleri ve Matematik Eğitimi Kongresi Bildiri Kitabı, Marmara Üniversitesi, İstanbul.

Popham, W.J. (2002). Classroom assessment: What teachers need to know? Boston: Allyn and Bacon.

Stronge, J.H., Tucker, P.D., \& Hindman, J.L. (2004). Handbook for qualities of effective teachers. VA: Association of Supervision and Cur. Dev.

Tan, Ş. (2007). Öğretimi Planlama ve Değerlendirme. Ankara: Pegem Akademi.

Tekin, H. (2019). Eğitimde dlçme ve değerlendirme (27. Baskı). Ankara: Yargı yayınevi

Usta, S., Çığır-Dikyol, D., \& İnce, E. (2010). The alternative evaluation tools choosen by social and science teacher candidates. Procedia Social and Behavioral Sciences, 2, 3457-3462.

Varış, F. (1996). Eğitimde program geliştirme, teori ve teknikler (6. Baskl). Ankara: Alkım.

Veronesi, P. (2000). Testing and assessment in science education: Looking past the scoreboard. The Clearing House 74(1), 27-30.

Yapıc1, M. ve Demirdelen, C. (2007). İlköğretim 4. sınıf programına ilişkin öğretmen görüşleri. İlköğretim Online, 6(2), 204- 212 
Yaşar, M. (2014). Eğitimde Ölçme ve Değerlendirme Dersine Yönelik Tutum Ölçeğinin Geliştirilmesi. Uluslararası Ĕgitim Bilimleri Araştırmaları Dergisi, 4(1);259-279.

Yaşar, Ş., Gültekin, M., Türkkan, B., Yıldız, N. Ve Girmen, P. (2005). Yeni İlköğretim Programlarının Uygulanmasına ilişkin Sınıf Öğretmenlerinin Hazırbulunuşluk Düzeylerinin ve Eğitim Gereksinimlerinin Belirlenmesi, Yeni İlköğretim Programlarını Değerlendirme Sempozyumu, Erciyes Üniversitesi, Kayseri

Yin, R. K. (2003). Case study research design and methods ( $3^{\text {rd }}$ ed.). California: Seğa Publications).

Yıldırım, A. ve Şimşek, H. (2016). Sosyal Bilimlerde Nitel Araştırma Yöntemleri, (10. Baskı) Ankara: Seçkin Yayınevi 


\title{
Ulakbilge
}

\section{ÖĞRENCİ DERS BAŞARISININ BELIRLENMESINDE ÖĞRETMEN ÖZELLIKLERININ ROLÜNÜN INCELENMESI}

\begin{abstract}
$\ddot{O} \mathbf{z}$
Eğitimi "kasıtlı kültürleme" süreci olarak tanımlarsak, tüm eğitsel faaliyetlerin planlı olması gereği ortaya çıkmaktadır. Eğitimde planlama, belirli eğitim hedeflerine ulaşmak için öğretim etkinliklerinden hangilerinin seçileceğinin, bunların öğrencilere niçin ve nasıl yaptırılacağının, ne gibi yardımcı ve tamamlayıcı kaynak ve araçların kullanılacağının ve elde edilen sonuçların nasıl değerlendirileceğinin önceden tasarlayıp kâğıt üzerinde düzenlenmesidir. Bu programların uygulayıcısı olan öğretmenler, tasarlanan planlı ve programlı eğitsel uygulamanın çıktılarını ya da ürününü en yakından gören ve takip eden eğitim sisteminin ana girdilerinden biridirler. Öğretmenler, çıktıların kalitesi hakkında en doğru ve en detaylı değerlendirmelere ulaşmak için, ürünü her boyutuyla incelemek, değerlendirme için en doğru ölçme araçlarıyla veri toplamak zorundadır. $\mathrm{Bu}$ araştırmanın amacı, öğrencilerin ders başarılarının belirlenmesi sürecinde, öğretmenlerin öğrencilere ait gözlenebilir sınıf içi ve sınıf dışı davranışlarını ne derece izleyip, değerlendirmede dikkate aldıklarını belirlemektir. Bu yönüyle araştırma betimsel nitelikte olduğundan, yöntem olarak tarama modellerinden tekil tarama kullanılmıştır. Araştırma; ilkokul, ortaokul ve lisede görevli gönüllü sınıf ve branş öğretmenleri üzerinde gerçekleștirilmiștir. Bu araștırma, sınıf içi ve sınıf dıșı öğrenci davranıșlarına ilișkin öğretmen gözlemlerinin ders başarılarının belirlenmesinde dikkate alınmasının önemini ortaya koymuştur. Elde edilen sonuçlara göre, öğretmenlerin öğrencilerin gözlenebilir sınıf içi ve sınıf dışı performans değişkenlerini değerlendirmede dikkate alma düzeylerinin cinsiyete, alan/branşa, kıdeme ve görev yapılan okulun kademesine/türüne göre anlamlı farklılaşma gösterdiği belirlenmiştir.
\end{abstract}

Anahtar Kelimeler: Eğitim, ders başarısı, ölçme, değerlendirme 